A N INTERNATIONAL JOURNAL

\title{
Tolerance to the Air Exposition Test of Hoplias lacerdae Larvae and Juvenile during Its Initial Development
}

\author{
Ronald Kennedy Luz and Maria Célia Portella* \\ Universidade Estadual Paulista; Centro de Aqüicultura; Via de Acesso Paulo Donato Castellane, s/n; Jaboticabal; \\ 14884-900; São Paulo - SP - Brasil
}

\begin{abstract}
The establishment of evaluation parameters for larvae and juvenile quality assessment is highly desirable. The experiment evaluated the Stress Resistance Rate $(\mathrm{Re})$ on Hoplias lacerdae larvae and juveniles. Larvae on the $13^{\text {th }}$, $16^{\text {th }}, 19^{\text {th }}, 23^{\text {rd }}$ and $26^{\text {th }}$ days of life were subjected to Re evaluation tests. Twenty animals were stoked in one liter beaker and kept at 27 to $28.5^{\circ} \mathrm{C}$. The following treatments were applied: E3 -3 minutes; E5 - 5 minutes; E7 - 7 minutes; E10 - 10 minutes and E15 -15 minutes on drying paper. After 24 hours Re was evaluated. It was observed that Re values showed an increase from $13^{\text {th }}$ to $19^{\text {th }}$ day in all treatments indicating an increasing resistance related to larval development. High Re rates were observed during the whole experiment, with the lowest value $(P<0.05)$ found on treatment E10 (67.7\% on the $13^{\text {th }}$ day) and E15 (41.25\% on the $26^{\text {th }}$ day). It could be concluded that trairao larvae and juvenile were resistant to the air exposition test on drying paper and expositions higher than seven minutes were more efficient for Re evaluation of trairao larvae and juveniles subjected to different rearing conditions.
\end{abstract}

Key words: Hoplias lacerdae, fish larvae, stress resistance

\section{INTRODUCTION}

Fish farming has been undertaking a process of production intensification to meet either a consumer market growing demand or the needs for larger quantities with better quality. For these reasons, many studies were oriented for the development of suitable and specific technology for intensive production system. The issues regarding the availability of juvenile fish are related mainly to the difficulties found during larviculture due to the occurrence of high mortality rates (Puvanendran and Brown 1999) caused by the use of unsuitable handling or lack of biological knowledge of the reared species (Basile-Martins, 1984; Fregadolli, 1993).
Juvenile fish production in Brazil is based on the conventional larviculture system whereby the larvae are stocked up in previously fertilized outdoor ponds for the production of plankton, the initial food for fish larvae (Senhorini et al., 1988; Senhorini et al., 1991; Fontes and Senhorini, 1994; Jomori et al., 2003). However, under these conditions, the animals are frequently subjected to stressing factors not only related to the scarce food which does not meet their nutritional requirement, but even the necessity of escaping from potential predators (Senhorini et al., 1991; Faria et al., 2001). Besides, handling, the transportation from hatchery to the ponds, as well as the release of the larvae in the rearing areas, might be taken into account as stressing points. Also, indoor

\footnotetext{
* Author for correspondence
} 
larviculture carried on at hatcheries can give rise to handling stressing situations for the animals. For instance, inadequate feeds (quantity and quality) (Luz and Zaniboni Filho, 2001; Luz, 2004), storage density (Kraul et al., 1992; Luz and Zaniboni Filho, 2002) and the lack of knowledge about the ideal parameters for water quality (Sipaúba-Tavares and Rocha, 1994), among others, are also stressing factors. As the intensification of the production systems occurs, appearance of diseases and growth interference originated from stress handling factors might eventually become a serious problem.

For the above-mentioned reasons, production efficiency during larviculture may be a great challenge to both researchers and breeders as an attempt to increase the availability of healthy animals suitable for the subsequent stages of the rearing cycle. Thus, from the economical point of view, an accurate appraisal of animal quality during their early life stages is very important (Planas and Cunha, 1999). The selection of individuals, which fit the rearing conditions, can be a way to obtain more resistant and productive animal strains. Yet, dealing with commercial rearing of native fish, studies of physiological stress are also recommendable, because the stress responses might vary from one species to another (Holanda et al., 2000).

Stress can be defined as a condition in which the dynamic balance of the animal is broken as a result of actions performed via intrinsic or extrinsic stimuli called stressors. In general, responses to stress can be seen as a change from anabolism to catabolism, allowing the use of the energetical reserves unavailable under normal conditions (Pickering, 1981).

The correlation of resistance to stress due to various stressing factors has been used as a criterion to evaluate production quality and as a back up for the results of growth and survival (Tackaert et al., 1989). Several resistance stress tests have been utilized, e.g., exposure to air (Ako et al., 1994; Benfey and Biron, 2000; Fryer, 1975; Koven et al., 2001; Kraul et al., 1993; Luz and Portella, 2002; Martins, et al., 2000; Sakakura et al., 1998), responses to bacteria inoculation (Chair et al., 1994; Gatesoupe, 1995), and to high ammonia levels (Mazik et al., 1987).

Trairao is considered a potential species for fish farming purposes (Neves, 1996) due its capacity of living in captivity (Andrade et al., 1998; Luz et al., 2001) and also for its accentuated rusticity
(Gontijo, 1984). However, even with the rise of information on respiratory physiology (Fernades et al., 1994; Kalinin et al., 1996; Rantin et al., 1992) and rearing techniques in the laboratory and captivity (Gontijo, 1984; Luz and Portella, 2002; Luz et al., 2001; Luz, 2004), there is no information about its resistance to stress. Thus, the objective of this work was to evaluate the resistance to air exposition that usually both larvae and juvenile fish displayed during initial development.

\section{MATERIAL AND METHODS}

The experiment was carried on at the Laboratory of Nutrition of Aquatic Organisms of CAUNESP, Brazil. Trairao larvae were stocked at the density of 30-50 larvae/L in a $100 \mathrm{~L}$ tank with constant aeration and continuous water flow. The tanks were covered with a black plastic to keep the animals under low luminosity (about 18 lux). Water temperature was maintained between 27 and $28.5^{\circ} \mathrm{C}$. In the beginning of exogenous feeding, eight days post-hatch larvae were sampled for initial total length measurement. They were fed daily with Artemia nauplii at 7,12 and 18 hours.

During the next 18 days, i.e. until 26 days of life, the animals were subjected to stress resistance tests through the exposition to air on a drying paper. The tests were held with animals with 13, 16, 19, 23 and 26 days of life. They were carefully siphoned into plastic bucket containers, counted and separated into 20 one-liter beakers, kept in a thermostatic bath system. In each beaker, 20 animals were held fasting for a period of six to eight hours. After this period, the animals were captured with a $0.5 \mathrm{~mm}$ mesh size and immediately put on drying paper (Atencio-García, 2000), making up the following treatments:

E3- 3 minutes on drying paper;

E5- 5 minutes on drying paper;

E7- 7 minutes on drying paper:

E10- 10 minutes on drying paper;

E15- 15 minutes on drying paper (treatment done with the 26-days-old- animals only, because of the high values found in the previous tests of 10 minutes).

Every experimental day had four repetitions in each treatment. At the end of each stressing period 
the animals used in the stress test were returned to the same beakers with new water and aeration. The animals that were found attached to the drying paper were carefully detached with the help of a paintbrush to avoid possible wounding. At the end of 24 hours, the survival was determined and this parameter was considered the stress resistance rate $(\operatorname{Re} \%)$. In each evaluation period, 30 animals were sampled from the rearing tank for measurement.

Stress resistance results were analyzed considering a completely randomized design following a subdivision scheme. The five main treatments were the time of air exposition on the drying paper (3, 5, 7, 10 and 15 minutes) and the secondary treatments were animals' age when resistance was evaluated (13, 16, 19, 23 and 26 days of life), with four replicates. Stress resistance rates (\%) were arcsine transformed. Statistical analyses (Variance Analysis and average comparisons by Tukey test) were done with Statistical Analysis System (SAS Institute Inc., version 6.12, 1999).

\section{RESULTS}

On the first test done (13-day old larvae), higher and lower Re values were observed on treatments E3 and E10, respectively (Table 1). At the $16^{\text {th }}$ day, the animals subjected to stress for three and five minutes $(\mathrm{E} 3$ and $\mathrm{E} 5)$ presented higher $\operatorname{Re}(\mathrm{P}<0.05)$ than those subjected to treatments E7 and E10. On the subsequent evaluation $\left(19^{\text {th }}\right.$ day), stress resistance rates were very high for all treatments (above 96\%), with no significant differences $(\mathrm{P}>0.05)$ among them. However, this trend was not maintained, and at the $23^{\text {rd }}$ day the average value for $\operatorname{Re}$ found for the smallest stress exposition $(\mathrm{E} 3)$ was significantly higher $(\mathrm{P}<0.05)$ than that obtained for the greatest exposition
(E10). Treatments E5 and E7 presented intermediate results. On the last evaluation (26 days), there were no significant differences $(\mathrm{P}>0.05)$ between treatments E3 and E5, but the animals on treatment E10 presented lower values $(\mathrm{P}<0.05)$ than those previously mentioned. The lowest resistance rates to stress were observed in treatment E15 $(\mathrm{P}<0.05)$.

During the whole experiment, Re values between treatments E3 and E5 were always similar and above $87 \%$, indicating that the 5-minute treatment on drying paper could be too short to evaluate stress resistance for these animals. Re values began to show differences from treatment E7, which can be considered the minimum stress time to be used for trairao larvae and juveniles to detect differences on the general state, under different management conditions. A 10 minute exposition would be better for trairao larvae and juvenile testing when general state differences under diverse rearing conditions need to be discriminated, since differences between this treatment and all others were observed throughout the period studied.

In general, it was observed that the animals exhibited an increase on stress resistance from $13^{\text {th }}$ to $19^{\text {th }}$ day of life (Table 1 ). However, at $23^{\text {rd }}$ and $26^{\text {th }}$ day there was a slight decrease on $\mathrm{Re}$, probably related to the occurrence of cannibalism among the animals and, also, due to greater size heterogeneity, which was detected both visually in the fish tanks as well as from the measurements (Table 2).

Observations done after the stress tests indicated that the animals presented loss of hydrostatic equilibrium during the first minutes after returning to the beakers and complete recovery between four and eight hours after the test. Animals that did not recover after this period did not survive.

Table 1 - Average values $( \pm \mathrm{SE})$ of Stress Resistance Rates $(\%)$ observed for Hoplias lacerdae larvae and juveniles exposed to different periods on drying paper, at different ages.

\begin{tabular}{cccccc}
\hline Treatment & $\mathbf{1 3}$ days old & 16 days old & 19 days old & 23 days old & 26 days old \\
\hline E3 & $96,2 \pm 7,5^{\mathrm{A} \mathrm{a}}$ & $100,0^{\mathrm{A} \mathrm{a}}$ & $100,0^{\mathrm{A} \mathrm{a}}$ & $93,7 \pm 4,8^{\mathrm{A} \mathrm{a}}$ & $97,5 \pm 5,0^{\mathrm{A} a}$ \\
E5 & $92,5 \pm 2,9^{\mathrm{AB} a b}$ & $96,2 \pm 4,8^{\mathrm{AB} \mathrm{a}}$ & $97,5 \pm 2,9^{\mathrm{AB} \mathrm{a}}$ & $87,5 \pm 2,9^{\mathrm{B} a b}$ & $98,7 \pm 2,5^{\mathrm{A} \mathrm{a}}$ \\
E7 & $76,3 \pm 13,7^{\mathrm{B} \mathrm{bc}}$ & $87,5 \pm 2,9^{\mathrm{AB} \mathrm{b}}$ & $96,3 \pm 4,7^{\mathrm{A} \mathrm{a}}$ & $90,0 \pm 7,1^{\mathrm{A} \mathrm{ab}}$ & $89,3 \pm 13,5^{\mathrm{A} \mathrm{ab}}$ \\
E10 & $67,7 \pm 7,8^{\mathrm{B}}$ & $77,5 \pm 6,5^{\mathrm{B} \mathrm{b}}$ & $97,5 \pm 5,0^{\mathrm{A} \mathrm{a}}$ & $78,7 \pm 4,8^{\mathrm{B} \mathrm{b}}$ & $70,7 \pm 9,9^{\mathrm{B} \mathrm{b}}$ \\
E15 & - & - & - & - & $41,2 \pm 13,1^{\mathrm{c}}$ \\
\hline
\end{tabular}

Means followed by the same letter (capital on the horizontal and small on the vertical) did not differ by Tukey test (P>0.05). 
Table 2 - Average values of length and weight $( \pm \mathrm{SE})$ observed for Hoplias lacerdae larvae and juveniles during the first 26 days of life

\begin{tabular}{ccc}
\hline Days of life & Length $\mathbf{( m m )}$ & Weight (mg) \\
\hline 8 & $9,58 \pm 0,39$ & $8,33 \pm 0,35$ \\
13 & $10,10 \pm 0,77$ & $9,33 \pm 0,25$ \\
16 & $11,81 \pm 0,81$ & $15,45 \pm 1,5$ \\
19 & $12,17 \pm 0,95$ & $19,20 \pm 1,80$ \\
23 & $12,81 \pm 1,80$ & $23,28 \pm 3,50$ \\
26 & $13,88 \pm 2,10$ & $33,80 \pm 8,50$ \\
\hline
\end{tabular}

\section{DISCUSSION}

Fishes in their initial life stages are more sensitive to stress than adults (Bonga, 1997). However, the animals were extremely resistant to the tests used in this study, indicating that larvae and juveniles of this species were not too sensitive to air exposition.

The trairao specimens presented high Re values in comparison to those found in yellowtail, Seriola quinqueradiata, subjected to a study on vitamin C effect (Sakakura et al., 1998). These authors ran an air exposition test for four minutes, after 20 days of feeding, and observed survival during the subsequent two hours. An improvement in stress resistance was observed on animals fed diet with increased vitamin $\mathrm{C}$, but survival levels varied from 30 to $40 \%$.

High survival levels, similar to those found in this study, were found in a stress resistance study with Mugil cephalus larvae in relation to feeding (Artemia, rotifers, and enriched Artemia), testing an animal stress exposition for 15 seconds, after 20 days of feeding treatment (Ako et al., 1994). The authors found a feeding treatment effect, since the larvae that received enriched nauplii presented greater survival on the stress resistance test, varying from 95.3 to $98.7 \%$, while those that received non enriched nauplii diet presented $\mathrm{Re}$ of only $27 \%$. However, in these two studies (Sakakura et al., 1998; Ako et al., 1994), the air exposition test was less drastic than the one done in the present study, where specimens of Hoplias lacerdae were also subjected to surface drying condition and loss of protection mucus due to the contact with the drying paper. In a previous experiment where the effect of water salinization was studied for initial rearing of trairao larvae fed with Artemia nauplii, $100 \%$ Re was found after 15 days of treatment, in all treatments (zero to $4 \%$ o salinity) in a three-minute test in drying paper (Luz and Portella, 2002). However, the results of this research indicated that perhaps the test was insufficient to detect possible Re differences.

Traira Hoplias malabaricus, a fish belonging to same family and genus of trairao, is very resistant to low levels of water dissolved oxygen. During the hypoxia period, a decrease in glucose in the tissues was observed, suggesting metabolical adaptations as a stress response (Moraes et al., 1996). This fish presents, for its survival under stress conditions, the strategy of reducing the metabolic activity to reduce oxygen demand. This resistance of fish to low oxygen levels in the water can also be related to the large glycogen deposits in muscle tissue and the ability that Hoplias species present for anaerobic metabolism (Driedzic et al., 1978).

In a study about Hoplias malabaricus and Hoplias lacerdae response to hypoxia (Kalinin et al., 1996), an increase in gill ventilation and respiration frequency was observed in both species. Trairao is a species that presents good response on gill ventilation and respiratory frequency under hypoxia (Fernandes et al., 1994; Rantin et al., 1992). These studies could be important to explain the fact that trairao larvae and juveniles were resistant to long periods of air exposition. In this perspective, detailed studies about respiratory frequency, gill ventilation, as well the effects of stress on animals' physiological conditions should be done to explain the high rates of Stress Resistance observed.

In general, an improvement in Re was observed with animal development. However, in the 10minute exposition treatment, there was a reduction on $\operatorname{Re}$ rates beginning on day 23, when cannibalism and animal size heterogeneity were detected in the rearing tanks, common facts in carnivore fish rearing. Cannibalism during trairao larviculture was reported by Luz (2004), as well as by Luz and Portella (2002). Social factors, competition for space or feed (Bonga, 1997) and social dominance stablishment among the animals 
(Carneiro and Urbinati, 1999) are factors that condition heterogeneous growth and, therefore, should be considered on stress related studies. However, less drastic tests (expositions below 7 minutes) were not discriminating.

Animal recovery time in this study varied from four to eight hours. In a previous study with trairao larvae (Luz and Portella, 2002), some of the animals were not completely recovered after two hours. This fact could be explained by the present study, where the animals needed a higher period for complete recovery. When fishes are exposed to mild stressing factors, a period of six hours is sufficient for animal recovery (Morales et al., 1990). This time was similar to that found for trairao larvae and juvenile for all treatments and different life stages. For trairao larvae and juveniles, 24 hours could be considered an adequate time to confirm stress response of animals subjected to air exposition on drying paper.

In summary, trairao larvae and juveniles presented high resistance to the stress applied, with high Re values, when exposed to treatments of three and five minutes on drying paper. Therefore, exposition times higher than seven minutes could be more adequate to evaluate $\mathrm{Re}$ of trairao under different rearing conditions.

\section{ACKNOWLEDGEMENTS}

The authors acknowledge CAPES for the scholarship to the first author and Estação de Pesquisa e Desenvolvimento Ambiental de Volta Grande -CEMIG for donating the larvae.

\section{RESUMO}

O estabelecimento de parâmetros para avaliação da qualidade de larvas e juvenis produzidos intensivamente é altamente desejável. Nesse sentido, o experimento teve o objetivo de avaliar a Taxa de Resistência ao Estresse (Re) em larvas e juvenis de trairão. Larvas foram submetidas a testes para a avaliação da $\operatorname{Re}$ no $13^{\circ}, 16^{\circ}, 19^{\circ}, 23^{\circ}$ e $26^{\circ}$ dia de vida. Vinte animais foram separados em béqueres de um litro e mantidos em temperatura entre 27 e $28,5^{\circ} \mathrm{C}$. Em seguida realizaram-se os seguintes tratamentos: E3. 3 minutos; E5. 5 minutos; E7. 7 minutos; E10. 10 minutos e E15. 15 minutos sobre o papel secante. Após 24 horas foi verificada a Re. Observou-se que a $\mathrm{Re}$ apresentou um aumento nos valores do $13^{\circ}$ ao $19^{\circ}$ dia em todos os tratamentos. Foram observadas elevadas Re durante todo o trabalho, sendo os menores valores $(\mathrm{P}<0,05)$ encontrados para E10 $\left(67,7 \%\right.$ no $13^{\circ}$ dia) e para E15 $(41,25 \%$ no $26^{\circ}$ dia). Concluiu-se que larvas e juvenis de trairão são resistentes à exposição ao ar sobre papel secante e que exposição superior a sete minutos é mais adequada para avaliação da Re de larvas e juvenis de trairão submetidos a diferentes condições de cultivo.

\section{REFERENCES}

Ako, H.; Tamaru, C. S.; Bass, P. and Lee, C. S. (1994), Enhancing the resistance to physical stress in larvae of Mugil cephalus by the feeding of enriched Artemia nauplii. Aquaculture, 122, 81-90.

Andrade, D. R.; Vidal, M. V. J. and Shimoda, E. (1998), Criação do trairão Hoplias lacerdae. Universidade Estadual do Norte Fluminense-UENF. Bol. Téc., 3, 23.

Atencio-García, V. J. (2000), Influência da primeira alimentação na alevinagem do yamú Brycon siebenthalae (EIGENMANN, 1912). Dissertação (Mestrado) - Universidade Federal de Santa Catarina.

Basile-Martins, M. A. (1984), Criação de organismos para alimentação de larvas de peixes. In: Simpósio Brasileiro de Aquicultura, São Carlos. Anais... São Carlos, São Paulo.

Benfey, T. J. and Biron, M. (2000), Acute stress response in triploid rainbow trout (Oncorhynchus mykiss) and brook trout (Salvelinus fontinalis). Aquaculture, 184, 167-176.

Bonga, S. E. W. (1997), The stress response in fish. Physiol. Rev., 77 : (3), 591-625.

Carneiro, P. C. F. and Urbinati, E. C. (1999), "Stress" e crescimento de peixes em piscicultura intensiva. In: Simpósio Sobre Manejo e Nutrição de Peixes, 3., Campinas. Anais... Campinas, São Paulo.

Chair, M.; Dehasque, M.; Van Poucke, S.; Nelis, H.; Sorgeloos, P. and De Leenheer, A. P. (1994), An oral challenge for turbot larvae with Vibrio anguillarum. Aquaculture Int., 2, 270-272.

Driedzic, W. R.; Phelger, C. F.; Fields, J. H. A. and French, C. (1978), Alteration in energy metabolism associated with the transition from water to breathing in fish. Can. J. Zool., 56, 730-735. 
Faria, A. C. A.; Hayashi, C. and Soares, C. M. (2001), Predação de larvas de pacu (Piaractus mesopotamicus) por copépodos ciclopóides (Mesocyclops lengisetus, Thiébaud) em diferentes densidades e ambientes e com diferentes contrastes visuais, Acta Scientiarum, 23 : (2), 497-502.

Fernandes, M. N.; Rantin, F. T.; Kalinin, A. L. and Moron, S. E. (1994), Comparative study of gill dimensions of three erythrinid species in relation to their respiratory function. Can. J. Zool., 72, 160-165.

Fontes, N. A. and Senhorini, J. A. (1994), Larvicultura do pacu Piaractus mesopotamicus Holmberg, 1887 (Teleostei Serrasalminae), em diferentes densidades de estocagem, B. Téc. CEPTA, 7, 49-58.

Fregadolli, C. H. (1993), Seleção alimentar de larvas de pacu Piaractus mesopotamicus Holmberg, 1887 e tambaqui Colossoma macropomum Cuvier,1818, em laboratório. B. Téc. CEPTA, 6 : (1),1-50.

Fryer, J. N. (1975), Stress and adrenocorticosteroid dynamics in the goldfish Carassius auratus. Can. J. Zool., 53, 1012-1020.

Jomori, R. K.; Carneiro, D. J.; Malheiros, E. B. and Portella, M. C. (2003), Growth and survival of pacu Piaractus mesopotamicus (Holmberg, 1887) juveniles reared in ponds or at different initial larviculture periods indoors. Aquaculture, 221, 277-287.

Gatesoupe, F. J. (1995), A method for the early assessment of the quality of turbot larvae. Aquaculture Int., 3, 150-154.

Gontijo, V. P. M. (1984), Produção consorciada de trairão e tilápia. Inf. Agropec., 10 : (110), 26-29.

Holanda, E. D.; Ribeiro, L. P. and Lima, L. C. (2000), Estresse e sua importância para a piscicultura. Inf. Agropec., 21 : (203), 83-85.

Kalinin, A. L.; Rantin, F. T.; Fernandes, M. N. and Glass, M. L. (1996), Ventilatory flow relative to intrabuccal and intraopercular volumes in two ecologically distinct erythrinids (Hoplias malabaricus and Hoplias lacerdae) exposed to normoxia and graded hypoxia. In: Val, A. L.; Almeida-Val, V. M. F. and Randall, D. J. (Eds.). Physiology and Biochemistry of the Fishes of the Amazon. Manaus : INPA. pp. 191-202.

Koven, W.; Barr, Y.; Lutzky, S.; Bem-Atia, I.; Weiss, R.; Harel, M.; Behrens, P. and Tandler, A. (2001), The effect of dietary arachidonic acid (20:4n-6) on growth, survival and resistance to handling stress in gilthead seabream (Sparus aurata) larvae. Aquaculture, 193, 107-122.

Kraul, S.; Ako, H.; Nelson, A.; Brittain, K. and Ogasawara, A. (1992), Evaluation of live feeds for larval and postlarval mahimahi Coryphaena hippurus. J. World Aquac. Soc., 23 : (4), 299-306.

Kraul, S.; Brittain, K.; Cantrell, R.; Nagao, T.; Ako, H.; Ogasawara, A. and Kitagawa, H. (1993), Nutritional factors affecting stress in the larva mahimahi Coryphaena hippurus. J. World Aquac. Soc., 24, 186-193.
Luz, R. K. (2004), Aspectos da larvicultura do trairão Hoplias lacerdae: manejo alimentar, densidade de estocagem e teste de exposição ao ar. Tese (Doutorado em Aqüicultura) - Universidade Estadual Paulista/Centro de Aquicultura-CAUNESP .

Luz, R. K. and Portella, M. C. (2002), Larvicultura de Trairão (Hoplias lacerdae) em Água Doce e Água Salinizada. Rev. Brasil. de Zootec., 31 : (2), 829-834.

Luz, R. K.; Salaro, A. L.; Souto, E. F.; Reis, A. and Sakabe, R. (2001), Desenvolvimento de alevinos de trairão com dietas artificiais em tanques de cultivo. Rev. Brasil. de Zootec., 30 : (4), 1159-1163.

Luz, R. K. and Zaniboni Filho, E. (2001), Utilização de diferentes dietas na primeira alimentação do mandiamarelo (Pimelodus maculatus, Lacépède). Acta Scientiarum, 23 : (2), 483-489.

Luz, R. K. and Zaniboni Filho, E. (2002), Larvicultura do mandi-amarelo Pimelodus maculatus Lacépède, 1803 (Siluriformes: Pimelodidae) em diferentes densidades de estocagem nos primeiros dias de vida. Rev. Brasil. de Zootec., 31 : (2),560-565.

Martins, M. L.; Moraes, F. R.; Moraes, J. R. E. and Malheiros, E. B. (2000), Falha na resposta do cortisol ao estresse por captura e por carragenina em Piaractus mesopotamicus Holmberg, 1887 (Osteichthyes: Characidae). Acta Scientiarum, 22 : (2), 545-552.

Mazik, P. M.; Bandtr, T. M. and Tomasso, J. R. (1987), Effects of dietary vitamin $\mathrm{C}$ on growth, caudal fin development, and tolerance of aquaculture-related stressors in Channel catfish. The Progr. Fish-Cult., 49, 13-16.

Moraes, G.; Oliveira, M. A. and Rantin, F. T. (1996), The metabolic pattern changes of Hoplias malabaricus from normoxia to hypoxia conditions. Rev. Brasil. de Biol., 56 : (2), 191-196.

Morales, A. E.; García-Rejón, L. and de La Higuera, M. (1990), Influence of handling and/or anesthesia in stress in rainbow trout. Effects on liver primary metabolism. Comp. Biochem. and Physiol., 95A : (1), 87-93.

Neves, C. A. (1996), Estudo morfológico e histoenzimológico do desenvolvimento ontogenético do trato digestivo de larvas e alevinos de trairão (Hoplias $c f$. lacerdae) e de pacamã (Lophiosilurus alexandri). Dissertação (Mestrado em Morfologia) Universidade Federal de Minas Gerais.

Pickering, A. D. (1981), The concept of biological stress. In: Pickering, A. D. (Ed.). Stress and fish. London: Academic Press, p.1-9.

Puvanendran, V. and Brown, J. A. (1999), Foraging, growth and survival of Atlantic cod reared in different prey concentrations. Aquaculture, 175, 77-92.

Planas, M. and Cunha, I. (1999), Larviculture of marine fish: problems and perspectives. Aquaculture, 177, 171-190. 
Rantin, F. T.; Kalinin, A. L.; Glass, M. L. And Fernandes, M. N. (1992), Respiratory responses to hypoxia in relation to mode of life of two species (Hoplias malabaricus and Hoplias lacerdae). J. Fish Biol., 41, 805-812.

Sakakura, Y.; Koshio, S.; Iida, Y.; Tsukamoto, K.; Kida, T. and Blom, J. H. (1998), Dietary vitamin C improves the quality of yellowtail (Seriola quinqueradata) seedlings. Aquaculture, 161, 427436.

Senhorini, J. A.; Figueredo, G. M.; Fontes, N. A. and Carolsfeld, L. (1988), Larvicultura e alevinagem do pacu, Piaractus mesopotamicus (Holmberg, 1887), tambaqui Colossoma macropomum (Cuvier, 1818) e seus respectivos híbridos. B. Téc. CEPTA, 1 : (2), 19-30.
Senhorini, J. A.; Fontes, N. A.; Lucas, A. F. B. and Santos Jr., S. (1991), Larvicultura do pacu Piaractus mesopotamicus Holmberg, 1887, (Pisces, Characidae) em viveiros com e sem organofosoforado (Folidol 60\%). B. Téc. CEPTA, 4 : (2), 11-22.

Sipaúba-Tavares, L. H. and Rocha, O. (1994), Sobrevivência de larvas de Piaractus mesopotamicus (Holmberg, 1887) (Pacu) e Colossoma macropomum (Cuvier, 1818) (Tambaqui), cultivadas em laboratório. Biotemas, 7 : (1-2), 46-56.

Tackaert, W.; Abelin, P.; Leger, P. H. and Sorgeloos, P. (1989), Stress resistance as a criterion to evaluate quality of postlarval shrimp reared under different feeding procedures. In: Simposio Brasileiro Sobre Cultivo de Camarão, 3., João Pessoa. Anais... João Pessoa, Brasil. 